\title{
COMPARATIVE VESSEL TRAITS OF MACARANGA GIGANTEA AND VATICA DULITENSIS FROM MALAYSIAN BORNEO
}

\author{
Jotan $\mathbf{P}^{1, *}$, Maycock $\mathbf{C R}^{1}$, Burslem DFRP ${ }^{2}$, Berhaman $\mathrm{A}^{1} \&$ Both $\mathrm{S}^{2,3}$ \\ ${ }^{1}$ Faculty of Science and Natural Resources, Universiti Malaysia Sabah, 88400 Kota Kinabalu, Malaysia \\ ${ }^{2}$ School of Biological Sciences, University of Aberdeen, Aberdeen, AB24 3UU, United Kingdom \\ ${ }^{3}$ School of Environmental and Rural Science, University of New England, Armidale 2351, NSW, Australia \\ *palasiahjotan@gmail.com
}

Submitted February 2019; accepted June 2019

\begin{abstract}
Trade-offs in wood anatomical characteristics reflect different strategies used by trees to deal with water transport in response to variation in environmental conditions. To study vascular strategies for Bornean rainforest trees, we compared water transport-related anatomical characteristics in branch wood between the common tree species Vatica dulitensis (Dipterocarpaceae) from old-growth forest and the common pioneer tree species Macaranga gigantea (Euphorbiaceae) from selectively logged forest. We hypothesised that the vessel traits of the pioneer species would reflect the need to capture and transport resources to support its fast growth rate (resource-acquisitive strategy), while the species of the old-growth forest would display more conservative vessel traits (resource-conservative strategy). We found that $M$. gigantea had significantly greater vessel area, hydraulically weighted diameter, vessel area to number ratio, and potential hydraulic conductivity than $V$. dulitensis. These results suggest that vessel traits of the common old-growth species would ensure high hydraulic safety during occasional drought when soil moisture is limited, while the common species of selectively logged forest possesses an efficient water transport system but its vessels would confer lower hydraulic safety during drought conditions. These contrasting vascular strategies highlight the potential for divergent responses of species of Bornean forest trees to future climatic extremes.
\end{abstract}

Keywords: Hydraulic conductivity, selective logging, old-growth forest, trade-off, tropical rainforest, wood anatomical traits

\section{INTRODUCTION}

The latest climate models predict that severe droughts will increase in frequency, duration and intensity across tropical regions over the next few decades (Zhang et al. 2015, Chadwick et al. 2016, Corlett 2016), which may result in increased mortality of forest trees (Bonal et al. 2016). Within the tropics, trees in aseasonal environments are most vulnerable to drought (Bonal et al. 2016, Corlett 2016). Moreover, widespread ongoing deforestation, selective logging and fragmentation of tropical rainforests create open patches in the landscape that result in more desiccating conditions for the residual forest canopies (Briant et al. 2010), thus exacerbating water shortage. Given the increasing incidence and extent of both droughts (Zhang et al. 2015, Corlett 2016) and anthropogenic pressures (Asner et al. 2009, Lewis et al. 2015) in the tropics, it is crucial to understand the wateruse strategies of trees in these ecosystems in order to support their conservation and management (Apgaua et al. 2015).
Borneo is recognised as a global biodiversity hotspot but has suffered some of the most intensive selective logging, deforestation and fragmentation across the tropics (Wilcove et al. 2013, Gaveau et al. 2014), leading to microclimate extremes (Blonder et al. 2018, Jucker et al. 2018). Bornean rainforests also experience extreme drought conditions induced by multi-annual El Niño Southern Oscillation (ENSO) events, causing severe tree mortality (Slik 2004, Van Nieuwstadt \& Sheil 2005). Under climate change, not only are mean temperature and precipitation predicted to rise and decline, respectively (IPCC 2013, Scriven et al. 2015), but the frequency and magnitude of ENSO droughts are also expected to increase in Borneo (Walsh \& Newbery 1999, Herbert \& Dixon 2003) and sharp increases in tree mortality after drought were reported recently from both Bornean primary and secondary forests (Qie et al. 2017). Hence an understanding of how trees cope with weather extremes is crucial for both preservation of old- 
growth forests and management and restoration of logged forests. However, water transport strategies remain poorly explored for tree species of either old-growth or logged forest in Borneo.

Functional water conducting systems are essential for both growth and survival of plants (Schreiber et al. 2015, Morris et al. 2018) especially when they are challenged by drought (Anderegg et al. 2016, Tng et al. 2018). Vessels in the tree stem play a key role in ensuring sufficient supply of water from roots to leaves (Zanne et al. 2010, Olson et al. 2014, Schreiber et al. 2015). Variation in xylem vessel anatomy is of major functional significance in trees (Carlquist 2001, Olson \& Rosell 2013). While large vessels transport water more efficiently than smaller ones, they are also prone to hydraulic failure (Meinzer et al. 2001, Hacke et al. 2006). Trees can adjust the efficiency and safety of their hydraulic systems by modifying vessel dimensions (Schreiber et al. 2015, Islam et al. 2019), vessel density (Islam et al. 2019), or the fraction of xylem occupied by vessel lumens (Zanne et al. 2010), and hence, altering their water-use strategies.

Vessel diameter is one of the most important wood anatomical traits because it affects hydraulic conductivity directly (Fichtler \& Worbes 2012, Scholz et al. 2013). Based on the Hagen-Poiseuille law, conductivity increases with the fourth power of the diameter (Tyree \& Zimmerman 2002), therefore, large vessels conduct water much more efficiently than small ones. When studying tree hydraulic characteristics, vessel diameter is often converted to hydraulically weighted vessel diameter (Olson et al. 2014), because the latter reflects the Hagen-Poiseuille law by giving more weight to larger vessels than smaller ones. Vessel area and vessel density (the latter also called vessel number per area) are useful predictors in studies of tree water transport because they define the amount of water that may be conducted in the stems (Tyree \& Zimmerman 2002). The wood anatomical characteristics vessel lumen fraction and vessel area to number ratio are alternative traits to describe vascular strategies and are both calculated from vessel area and vessel density (Zanne et al. 2010). Vessel lumen fraction indicates the amount of cross-sectional area covered by vessels. Vessel area to number ratio measures the variation in vessel composition in the conducting area. A higher value indicates the presence of few large vessels that are highly efficient in transporting water while lower values characterise numerous small vessels and a more conservative hydraulic strategy (Zanne et al. 2010).

Different combinations of vessel sizes, densities and fractions reflect different strategies used by trees to deal with water transport under varying environmental conditions (Apgaua et al. 2015). When grown with sufficient soil moisture, the wide, rapidly conducting (but embolism-prone) vessels support fast tree growth, but when subjected to water deficit, the narrow slowly conducting (but embolismresistant) vessels are needed to ensure hydraulic safety (Olson et al. 2014, Apgaua et al. 2017). This hydraulic efficiency-embolism resistance trade-off may play a key role in tree survival in environments such as the aseasonal tropics that do not experience regular annual dry seasons. When these ecosystems are exposed to occasional severe droughts, tree xylem anatomy determines whether cavitation is maintained at non-fatal levels while at the same time meeting the needs of the tree for transpiration.

In this study we compared wood density and six water transport-related wood anatomical characteristics between two common tree species representing, respectively, old-growth and selectively logged forest in Sabah, Malaysian Borneo. Specifically, we investigated differences in vessel area (A), hydraulically weighted vessel diameter $\left(D_{h}\right)$, vessel lumen fraction $(F)$, vessel number per area $(\mathrm{N})$, vessel area to number ratio $(\mathrm{S})$, potential hydraulic conductivity $\left(\mathrm{K}_{\mathrm{p}}\right)$ and wood density between Vatica dulitensis (Dipterocarpaceae), which is a representative species of unlogged primary forest and Macaranga gigantea (Euphorbiaceae) from selectively logged forest. Macaranga gigantea is a typical pioneer species invading logging gaps in secondary forests (Slik et al. 2003, Susanto et al. 2016), while $V$. dulitensis is a canopy species that is endemic to Borneo and possesses shade-tolerant seedlings (Soepadmo et al. 2004). Pioneer species are known for having much lower wood density than slow-growing shade-tolerant species (King et al. 2006). However, studying wood density alone is not sufficient to fully understand water transport in trees because tree species with similar wood density may differ significantly in their xylem anatomy (Ziemińska et al. 2013) and consequently also in their hydraulic conductivity. Additional anatomical traits such as vessel 
characteristics can support the detection of fine scale water-use strategies. Although $M$. gigantea and $V$. dulitensis are common species in Bornean secondary and primary forests respectively, to the best of our knowledge, their vessel traits and hydraulic conductivity have not been examined.

We tested the hypothesis that vessel traits of the common pioneer species would reflect the need to capture and transport resources to support its fast growth rate, while the common shade-tolerant species of old-growth forest would display more conservative vessel traits. Therefore, because conductivity of vessels in angiosperms is associated with vessel area and diameter (Zanne et al. 2010), we expected that the pioneer $M$. gigantea would have larger vessel area, larger hydraulically weighted diameter and larger vessel area to number ratio than the shadetolerant species $V$. dulitensis. According to the Hagen-Poiseuille law, the hydraulic conductivity increases proportionally with the fourth power of conduit diameter (Tyree \& Zimmerman 2002), and thus most of the conductivity in trees can be contributed by a few large vessels (Westoby \& Wright 2006). Therefore, we hypothesised that $M$. gigantea would have greater number of large vessels than $V$. dulitensis and therefore higher potential conductivity. We expected that the presence of large vessels in the former would also lead to lower vessel number per area compared with the latter. We expected wood density to be significantly lower in the pioneer $M$. gigantea than in shade-tolerant $V$. dulitensis. Since wood density is directly linked to the non-lumen fraction and the denser the wood is, the larger the proportion of the non-lumen fraction (Zanne et al. 2010, Scholz et al. 2013), we anticipated the vessel lumen fraction to be greater in the low-density wood of M. gigantea than in that of $V$. dulitensis.

\section{MATERIALS AND METHODS}

\section{Study area}

The study was based on samples collected from two study sites in Sabah, Malaysia, northern Borneo (Figure 1), that are part of the Global Ecosystem Monitoring network (www.gem. tropicalforests.ox.ac.uk). One site was in the old-growth lowland dipterocarp forest in Maliau Basin Conservation Area, which is located in central Sabah (centred on $4^{\circ} 49^{\prime} \mathrm{N}, 116^{\circ} 54^{\prime}$ $\mathrm{E}, 58,840 \mathrm{ha}$ ). The other study site was located in the selectively logged forest in Kalabakan Forest Reserve which is part of the Stability of Altered Forest Ecosystems Project (SAFE, Ewers

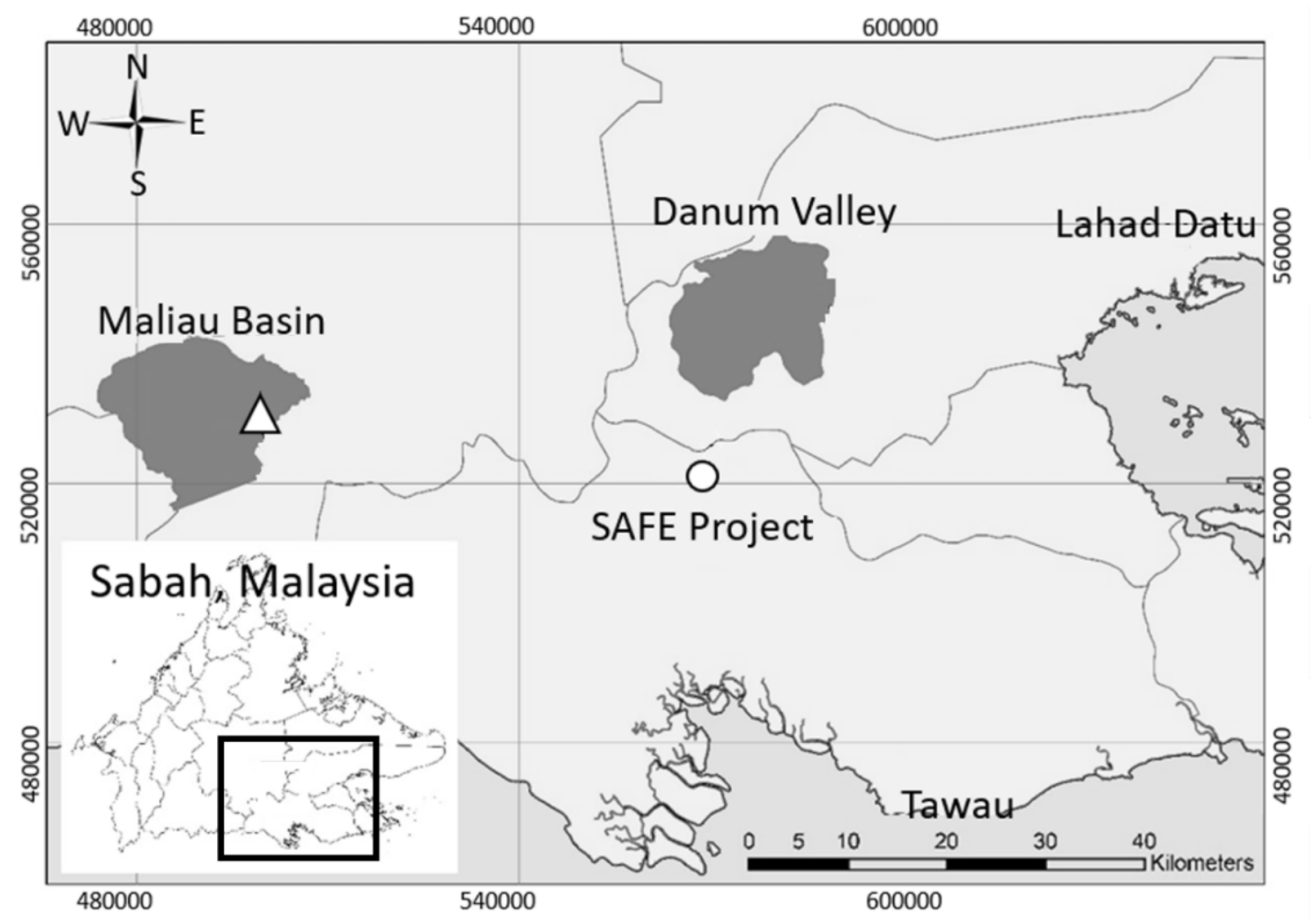

Figure 1 Map of the two study sites in Sabah, Malaysia (triangle and circle show the approximate sampling locations); Maliau Basin Conservation Area (triangle) represents old-growth forest while the Stability of Altered Forest Ecosystems (SAFE) Project (circle) contains selectively logged forest 
et al. 2011). The SAFE area was subjected to one round of selective logging in the 1970s (removing $113 \mathrm{~m}^{3} \mathrm{ha}^{-1}$ ) and then up to three rounds of logging in 1990-2008 (removing a further $66 \mathrm{~m}^{3} \mathrm{ha}^{-1}$ ) (Ewers et al. 2015). As a consequence, the SAFE area possesses few emergent trees and is dominated by pioneers and invasive tree species with a high density of logging roads and skid trails (Pfeifer et al. 2016).

\section{Data collection}

In this study, we targeted common tree species with regard to abundance and basal area in oldgrowth forest ( $V$. dulitensis) and selectively logged forest ( $M$. gigantea) as part of a comprehensive functional trait sampling (Both et al. 2019). In 2015, we collected branch wood samples for a total of six individuals of $V$. dulitensis in Maliau Basin Conservation Area. Stem diameter at breast height $(\mathrm{DBH})$ for $V$. dulitensis was $24.0 \pm$ $13.1 \mathrm{~cm}$ (mean value \pm standard deviation, $\mathrm{N}=$ $6)$. In the selectively logged forest site, a total of six $M$. gigantea individuals were sampled. Mean DBH of sampled $M$. gigantea individuals was 21.9 $\pm 7.3 \mathrm{~cm}(\mathrm{~N}=6)$. Tree canopies were accessed by professional tree climbers and branches with wood diameter of approximately $1.5 \mathrm{~cm}$ (wood diameter measured under bark) were collected from each target tree (one branch per tree). The branches were further cut into small sections, approximately $5 \mathrm{~cm}$ long, with a fine hand saw, stored in cooled, sealed plastic bags and brought to the laboratory for further processing (PérezHarguindeguy et al. 2013). Fresh wood volume was measured for each branch wood sample using the water displacement method. Wood samples were dried at $70{ }^{\circ} \mathrm{C}$ for 72 hours. Wood density $\left(\mathrm{g} \mathrm{cm}^{-3}\right)$ was calculated as dry mass divided by the fresh wood volume.

For each tree individual, branch sections were analysed for anatomical traits. The samples were placed in formalin-acetic acid-alcohol (FAA) fixative in $50 \mathrm{~mL}$ conical tubes within 24 hours of collection. The FAA was prepared in proportions of 90:5:5 (70\% ethanol:glacial acetic acid:formalin) (Johansen 1940). After 4 weeks the fixative agent was replaced with $70 \%$ ethanol. The $70 \%$ ethanol solution was then replaced two times within 10 days to wash the fixative out and the third change of ethanol as a storage medium. Eight cross-sections were made for each sample with a sliding microtome at 10-20 $\mu \mathrm{m}$ thickness using disposable blades. Sections were stained in a mixture of Safranin $\mathrm{O}$ and Alcian blue for better contrast and tissue identification. All sections were mounted in glycerol on a microscope slide, covered with a cover slip and sealed with nail polish. Of the eight cross-sections for each sample, the most representative was selected for image processing and analysis.

\section{Image processing and data analysis}

Photographs of the selected cross-sections were taken at $10 \times$ magnification using a digital camera attached to a light microscope and image capturing software (Figure 2). The scale was calibrated with a standard ocular micrometer slide. Several images per crosssection were taken from the cambium to the pith. The series of images was merged together in Image Composite Editor software (version
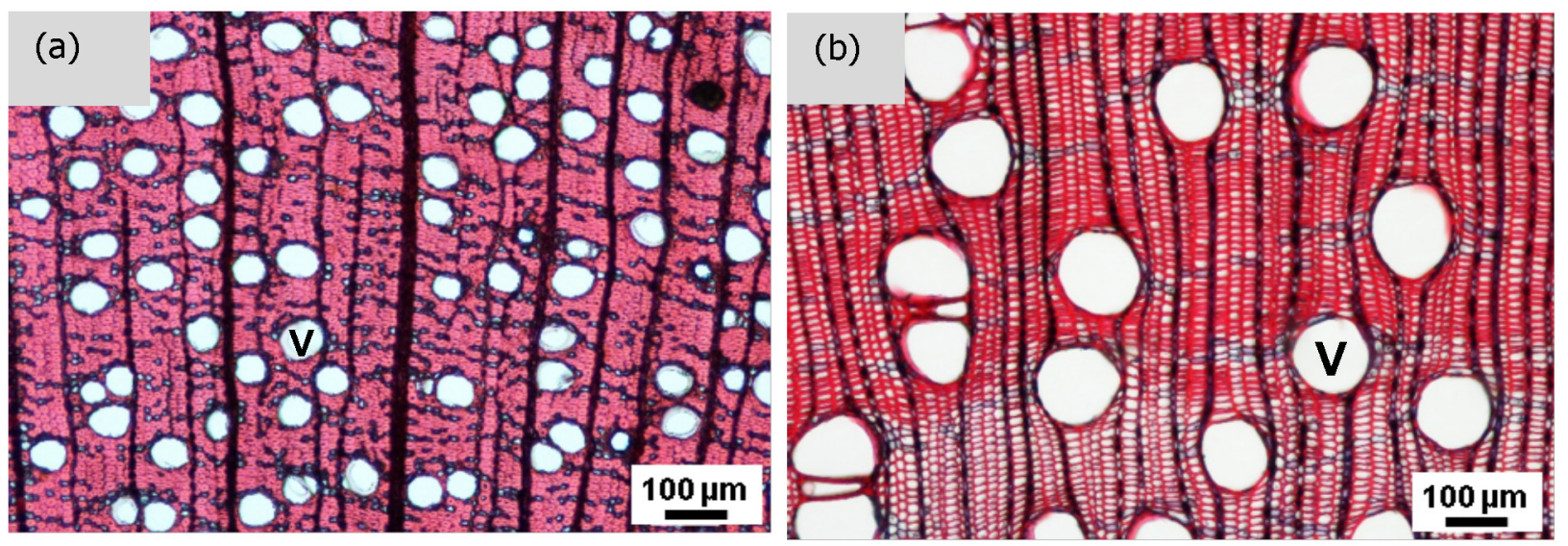

Figure 2 Illustration of wood cross-sections of (a) Vatica dulitensis and (b) Macaranga gigantea; V indicates a vessel 
2.0.3.0). The cross-sectional areas and vessel traits of the wood tissues were measured on one wedge-shaped transect per sample. The wedge-shaped transect was placed where tension wood was absent and the vessels were not, or only to a small degree, damaged by the process of sectioning. Vessel lumens were coloured in GIMP software (version 2.8.16, GNU Image Manipulation Program) using a Cintiq 13HD graphic tablet. All vessels in the transect were analysed with Image J 1.50i software.

The anatomical traits measured in this study were vessel area (A) determined by the average cross-sectional area of all vessel lumens (excluding vessel walls) in the wedge-shaped transect, vessel diameter determined as the mean of the maximum and minimum (lumen) diameters because vessels often were not exactly circular, and total area of all vessels in each cross-sectional image. For each species, vessel area and vessel diameter were averaged across individuals. From the vessel areas and transect areas, vessel lumen fraction (F) was calculated as the fraction of transect area filled by vessel lumens (Zanne et al. 2010). Other vessel characteristics calculated in the present study were hydraulically weighted diameter $\left(D_{h}\right)$, vessel number per area $(\mathrm{N})$ and vessel area to number ratio (S) (also called the average vessel area to number of vessels per area ratio).

Hydraulically weighted diameter $=\left(\sum\right.$ diameter $\left.^{5}\right) /\left(\sum\right.$ diameter $\left.^{4}\right)$ which weights the importance of diameter in estimated hydraulic conductance following Sperry et al. (1994). Vessel number per area (N) was calculated as vessel lumen fraction in the cross-section $(\mathrm{F})$ divided by vessel area (A), i.e. $\mathrm{N}=\mathrm{F} / \mathrm{A}$, and vessel area to number ratio (S) was calculated as vessel area divided by vessel number per area $(\mathrm{S}=$ $\mathrm{A} / \mathrm{N}$ ) which measures the variation in vessel size composition. A higher value of $\mathrm{S}$ denotes a greater contribution of large vessels to water conduction which are efficient at fast water transport (Zanne et al. 2010). Anatomical terminology follows IAWA Committee (1989). Potential (theoretical) hydraulic conductivity $\left(\mathrm{K}_{\mathrm{p}}\right)$ was calculated following Poorter et al. (2010) $\left(\mathrm{K}_{\mathrm{p}}=\left(\pi \rho_{\mathrm{w}} / 128 \eta\right)\right.$ $\times \mathrm{N} \times \mathrm{D}_{\mathrm{h}}{ }^{4}$, where $\mathrm{K}_{\mathrm{p}}$ is the potential (xylem area-specific) hydraulic conductivity (in $\mathrm{kg}^{\cdot} \mathrm{m}^{-1}$ $\left.\mathrm{MPa}^{-1} \mathrm{~s}^{-1}\right), \rho_{\mathrm{w}}$ is the density of water at $20^{\circ} \mathrm{C}(998.2$ $\left.\mathrm{kg} \mathrm{m}^{-3}\right)$, and $\eta$ is the viscosity of water at $20^{\circ} \mathrm{C}$ $\left.\left(1.002 \times 10^{-3} \mathrm{~Pa} \mathrm{~s}\right)\right)$. Differences in traits between the two species were tested with a non-parametric ANOVA and subsequent Kruskal-Wallis test. All statistical analyses were performed using R 3.4.3 (R Core Team 2017).

\section{RESULTS}

There were clear differences in wood anatomical traits between $V$. dulitensis and M. gigantea (Table $1)$. Vessel area was significantly smaller in $V$. dulitensis (average: $0.002 \mathrm{~mm}^{2}$ ) compared with $M$.

Table 1 Summary of wood anatomical traits of Vatica dulitensis and Macaranga gigantea; average, minimum, and maximum values are shown

\begin{tabular}{|c|c|c|c|c|c|c|c|c|c|c|}
\hline \multirow[t]{2}{*}{ Trait } & \multicolumn{4}{|c|}{ V. dulitensis } & \multicolumn{4}{|c|}{ M. gigantea } & \multicolumn{2}{|c|}{ Kruskal-Wallis } \\
\hline & Min & Max & Average & $\begin{array}{c}\mathrm{N} \text {-fold } \\
\text { variation }\end{array}$ & Min & Max & Average & $\begin{array}{c}\mathrm{N} \text {-fold } \\
\text { variation }\end{array}$ & $\begin{array}{c}\chi^{2} \\
(\mathrm{df}=1)\end{array}$ & $\mathrm{p}$ \\
\hline Vessel area, A $\left(\mathrm{mm}^{2}\right)$ & 0.001 & 0.003 & $0.002^{\mathrm{a}}$ & 1.96 & 0.004 & 0.007 & $0.006^{\mathrm{b}}$ & 1.69 & 8.308 & 0.004 \\
\hline $\begin{array}{l}\text { Hydraulically } \\
\text { weighted diameter, } \\
\mathrm{D}_{\mathrm{h}}(\mathrm{mm})\end{array}$ & 0.052 & 0.072 & $0.061^{\mathrm{a}}$ & 1.40 & 0.097 & 0.119 & $0.110^{\mathrm{b}}$ & 1.23 & 8.308 & 0.004 \\
\hline $\begin{array}{l}\text { Vessel lumen fraction, } \\
\text { F (unitless) }\end{array}$ & 0.128 & 0.184 & $0.149^{\mathrm{a}}$ & 1.43 & 0.094 & 0.173 & $0.144^{\mathrm{a}}$ & 1.85 & 0.000 & 1.000 \\
\hline $\begin{array}{l}\text { Vessel number per } \\
\text { area, } \mathrm{N}\left(\mathrm{mm}^{-2}\right)\end{array}$ & 60.05 & 101.90 & $80.72^{\mathrm{a}}$ & 1.70 & 17.91 & 41.40 & $25.01^{\mathrm{b}}$ & 2.31 & 8.308 & 0.004 \\
\hline $\begin{array}{l}\text { Vessel area to number } \\
\text { ratio, } \mathrm{S}\left(\mathrm{mm}^{4}\right)\end{array}$ & $1.35 \times 10^{-5}$ & $3.97 \times 10^{-5}$ & $2.55 \times 10^{-5}$ a & 2.94 & 0.0001 & 0.0004 & $0.0003^{\mathrm{b}}$ & 3.84 & 8.308 & 0.004 \\
\hline $\begin{array}{l}\text { Potential hydraulic } \\
\text { conductivity, } \\
\mathrm{K}_{\mathrm{p}}\left(\mathrm{kg} \mathrm{m}^{-1} \mathrm{MPa}^{-1} \mathrm{~s}^{-1}\right)\end{array}$ & 10.36 & 67.79 & $31.02^{\mathrm{a}}$ & 6.54 & 38.55 & 201.34 & $99.53^{\mathrm{b}}$ & 5.22 & 5.769 & 0.016 \\
\hline Wood density $\left(\mathrm{g} \mathrm{cm}^{-3}\right)$ & 0.606 & 0.962 & $0.717^{\mathrm{a}}$ & 1.59 & 0.296 & 0.407 & $0.355^{\mathrm{b}}$ & 1.38 & 8.308 & 0.004 \\
\hline
\end{tabular}

$\mathrm{N}$-fold variations expressed as the ratio of maximum to minimum values; lowercase letters signify differences $(a=0.05)$ between the species based on a Kruskal-Wallis test 
gigantea $\left(0.006 \mathrm{~mm}^{2}\right)$ (ranging from $0.001-0.003$ and $0.004-0.007 \mathrm{~mm}^{2}$, respectively). Hydraulically weighted diameter reached 0.052-0.072 and $0.097-0.119 \mathrm{~mm}$ in $V$. dulitensis and M. gigantea respectively. Vessel number per area in $V$. dulitensis (average: $80.72 \mathrm{~mm}^{-2}$ ) was three times higher than in $M$. gigantea $\left(25.01 \mathrm{~mm}^{-2}\right)$. Vessel area to number ratio was significantly higher in $M$. gigantea (average: $0.0003 \mathrm{~mm}^{4}$ ) compared with $V$. dulitensis $\left(0.0000255 \mathrm{~mm}^{4}\right)$. Potential hydraulic conductivity ranged from 10.36 to $67.79 \mathrm{~kg} \mathrm{~m}^{-1} \mathrm{MPa}^{-1} \mathrm{~s}^{-1}$ in $V$. dulitensis, while $M$. gigantea exhibited significantly higher values of 38.55 to $201.34 \mathrm{~kg} \mathrm{~m}^{-1} \mathrm{MPa}^{-1} \mathrm{~s}^{-1}$. Wood density was significantly higher in $V$. dulitensis (ranging from 0.606-0.962 $\mathrm{g} \mathrm{cm}^{-3}$ ) than in M. gigantea $\left(0.296-0.407 \mathrm{~g} \mathrm{~cm}^{-3}\right.$ ) (Table 1). No significant difference was found between species for vessel lumen fraction.

\section{DISCUSSION}

Our study revealed significant differences in almost all studied wood anatomical traits between representative species of old-growth and selectively logged Bornean forests. The latesuccessional species $V$. dulitensis displayed more conservative traits (such as significantly smaller vessel area and vessel diameter, but higher vessel density; Table 1) than the pioneer $M$. gigantea from selectively-logged forest. Vatica dulitensis lacked large vessels and showed lower values of both vessel area to number ratio and potential hydraulic conductivity. The small vessel size and high wood density displayed by $V$. dulitensis are vascular traits strengthening hydraulic safety and are indicative of a conservative resource acquisition and growth strategy. Small vessels are associated with high resistance to xylem cavitation and are an adaptation to prevent reduction in hydraulic conductivity during drought (Preston et al. 2006, Robert et al. 2009, Apgaua et al. 2017, Islam et al. 2018). Dense vessels lower the risk of detrimental damage during stressful environmental conditions by enabling alternative pathways for water conductivity when cavitation occurs (Schmitz et al. 2006). Vatica dulitensis is a slow-growing shade-tolerant species (Still 1993), and its vessel traits are unlikely to need a high hydraulic efficiency to support rapid transpiration. Instead they would ensure high hydraulic safety during occasional droughts when soil moisture is limiting. In contrast, pioneer species such as $M$. gigantea grow in open forest gaps created by selective logging (Verburg \& Van Eijk-Bos 2003). In gaps, increased light availability is the deciding factor for increased Macaranga species abundance (Davies 2001). However, increased irradiance also imposes a demand for higher transpiration requirements to sustain high photosynthetic and growth rates, therefore pioneers must exhibit a highly efficient water conducting system. In the present study, $M$. gigantea showed higher potential hydraulic conductivity resulting from large vessels and high vessel area to number ratio. Species possessing large vessels and a high vessel area to number ratio benefit from efficient water transport but face a greater risk of embolism (Zanne et al. 2010). Furthermore, low vessel density contributes to vulnerability of the tree to drought because of the lack of alternative pathways if numerous vessels are embolised during cavitation. Hence, $M$. gigantea has developed an efficient water transport system but lacks hydraulic safety under drought conditions. Clear differences in five out of six water transport-related vessel traits between the common species of old-growth and selectively logged forests may indicate that the tree communities occupying these forest types differ significantly in their resistance to drought, if the two species sampled in this study are representative of those communities in terms of vessel traits.

Based on our results, pioneer-dominated logged forests may be much more susceptible to low soil moisture than old-growth forests, because pioneers lack the safety of their hydraulic systems. Our findings corroborate those of Slik (2004) who found increased mortality of pioneer Macaranga trees in logged forests during the 1997/98 ENSO drought. This finding has important implications for the future of logged Bornean forests, because under climate change, extreme drought events occurring during ENSO events are expected to increase in both frequency and magnitude (Walsh \& Newbery 1999, Herbert \& Dixon 2003, McAlpine et al. 2018, Freund et al. 2019). Moreover, while both old-growth and selectively logged Bornean forests experience supra-annual extreme droughts under ENSO, these impacts of drought may be further worsened in selectively logged forests because they suffer additional microclimate extremes resulting from their open canopies (Blonder et al. 2018, Jucker et al. 2018). 
The two studied species differed significantly in all traits except for vessel lumen fraction. Vessel lumen fraction indicates the relative amount of space in the stem available for water transport. Some authors have suggested that vessel lumen fraction should be negatively correlated with wood density (Scholz et al. 2013), however, many studies have found this relationship to be weak or non-existent (Martínez-Cabrera et al. 2009, Poorter et al. 2010, Zanne et al. 2010). Results showed that while wood density of $V$. dulitensis was twice that of $M$. gigantea, the two species did not differ significantly in the vessel lumen fraction. Our results thus support findings of Ziemińska et al. (2013) who argued that wood density alone is not sufficient to understand water transport in trees. The absence of a difference in vessel lumen fraction between the dense wood of $V$. dulitensis (mean wood density $0.72 \mathrm{~g} \mathrm{~cm}^{-3}$ ) and the light wood of the pioneer $M$. gigantea $\left(0.36 \mathrm{~g} \mathrm{~cm}^{-3}\right)$ may be explained by the difference in the density of the matrix tissue outside the vessel lumens (Fan et al. 2012). Despite having lower conductivity due to the small size of vessels, $V$. dulitensis may partially increase the efficiency of its hydraulic system by possessing a high density of vessels, while at the same time maintaining a high wood density.

Selective logging causes shifts in the range of various leaf and wood trait values in the tree community (Baraloto et al. 2012, Both et al. 2019, Carreño-Rocabado et al. 2012, Mayfield et al. 2013, Mouillot et al. 2013, Osazuwa-Peters et al. 2015). Nonetheless, to our knowledge, there has been no study comparing vessel traits between representative species of logged and unlogged tree communities. Campbell et al. (2016, 2018) analysed differences in vessel characteristics between logged and undisturbed forests in the Brazilian dry and wet tropics; however, both studies focused on a single tree species only. There is a gap of knowledge comparing wood anatomical traits between species of old-growth and selectively logged tree communities. The rising proportion of fragmented and disturbed forest in the tropics (Lewis et al. 2015) adds urgency to the need to understand how plant functional traits of abundant species vary in response to disturbance and how these changes determine ecosystem functioning (Both et al. 2019).

\section{CONCLUSIONS}

This study is the first step in filling this gap in our understanding of differences in tree vessel traits between old-growth and selectively logged rainforests in Borneo. Despite the limitation of analysing only two species in our study, the outcomes highlight an important potential difference in vascular strategies for trees in Bornean rainforest. Further research is needed to explore vessel traits of whole tree communities in both primary and secondary forests. Future studies should examine the relationships among vessel traits, tree size and crown exposure to light. Our results indicate low hydraulic safety in an abundant pioneer species of selectively logged forests. Therefore, our findings suggest an important limitation on forest resilience during future climatic extremes if species in selectively logged forest are prone to hydraulic failure and subsequent mortality.

\section{ACKNOWLEDGEMENTS}

This study was funded by the UK Natural Environment Research Council (NE/ K016253/1) and (GL00149). We thank Ziemińska $\mathrm{K}$, Weitz HJ, Buckingham J for laboratory support and Kruitbos L and Jami U for logistical assistance. We thank the Sabah Biodiversity Council, Sabah Foundation, the Maliau Basin Management Committee, the South East Asia Rainforest Research Partnership, the Sime Darby Foundation and the SAFE Project. This study is a contribution from the Biodiversity and Land-use Impacts on Tropical Ecosystem Function (BALI) consortium (http://bali.hmtf.info) funded by the UK Natural Environment Research Council.

\section{REFERENCES}

Anderegg WRL, Klein T, Bartlett M et Al. 2016. Metaanalysis reveals that hydraulic traits explain crossspecies patterns of drought-induced tree mortality across the globe. Proceedings of the National Academy of Sciences 113: 5024-5029. https://doi.org/10.1073/ pnas. 1525678113.

Apgaua DMG, Ishida FY, Tng DYP eT al. 2015. Functional traits and water transport strategies in lowland tropical rainforest trees. PLoS ONE 10: e0130799. https://doi.org/10.1371/journal.pone.0130799.

Apgaua DMG, Tng DY, Cernusak L et Al. 2017. Plant functional groups within a tropical forest exhibit different wood functional anatomy. Functional 
Ecology 31: 582-591. https://doi.org/10.1111/13652435.12787.

Asner GP, Rudel, TK, Aide TM, Defries R \& Emerson R. 2009. A contemporary assessment of change in humid tropical forests. Conservation Biology 23: 1386-1395. https://doi.org/10.1111/j.1523-1739.2009.01333.x.

Baraloto C, Hérault B, Paine CET et al. 2012. Contrasting taxonomic and functional responses of a tropical tree community to selective logging. Journal of Applied Ecology 49: 861-870. doi: 10.1111/j.13652664.2012.02164.x

Blonder B, Both S, Coomes DA et al. 2018. Extreme and highly heterogeneous microclimates in selectively logged tropical forests. Frontiers in Forests and Global Change 1: 5. https://doi.org/10.3389/ ffgc.2018.00005.

Bonal D, Burban B, Stahl C, Wagner F \& Hérault B. 2016. The response of tropical rainforests to droughtlessons from recent research and future prospects. Annals of Forest Science 73: 27-44. doi: 10.1007/ s13595-015-0522-5.

Both S, Riutta T, Paine CET et al. 2019. Logging and soil nutrients independently explain plant trait expression in tropical forests. New Phytologist 221: 1853-1865. https://doi.org/10.1111/nph.15444.

Briant G, Gond V \& Laurance SGW. 2010. Habitat fragmentation and the desiccation of forest canopies: a case study from eastern Amazonia. Biological Conservation 143: 2763-2769. https://doi. org/10.1016/j.biocon.2010.07.024.

Campbell G, Mielke MS, Rabelo GR \& Da Cunha M. 2018. Key anatomical attributes for occurrence of Psychotria schlechtendaliana (Müll. Arg.) Müll. Arg. (Rubiaceae) in different successional stages of a tropical moist forest. Flora: Morphology, Distribution, Functional Ecology of Plants 246-247: 33-41. https://doi.org/10.1016/j. flora.2018.07.004

Campbell G, Rabelo GR, Cunha M DA \& Da Cunha M. 2016. Ecological significance of wood anatomy of Alseis pickelii Pilg. \& Schmale (Rubiaceae) in a tropical dry forest. Acta Botanica Brasilica 30: 124-130. http:// dx.doi.org/10.1590/0102-33062015abb0267.

Carlquist S. 2001. Comparative Wood Anatomy. Systematic, Ecological, and Evolutionary Aspects of Dicotyledon Wood. Second edition. Springer, Berlin.

Carreño-Rocabado G, Peña-Claros M, Bongers F, Alarcón A, Licona JC \& PoOrter L. 2012. Effects of disturbance intensity on species and functional diversity in a tropical forest. Journal of Ecology 100: 1453-1463. doi: 10.1111/j.1365-2745.2012.02015.x.

Chadwick R, Good P, Martin G \& Rowell DP. 2016. Large rainfall changes consistently projected over substantial areas of tropical land. Nature Climate Change 6: 177-181. https://doi.org/10.1038/ nclimate2805.

Corlett RT. 2016. The impacts of droughts in tropical forests. Trends in Plant Science 21: 584-593. https:// doi.org/10.1016/j.tplants.2016.02.003.

DAVIES SJ. 2001. Tree mortality and growth in 11 sympatric Macaranga species in Borneo. Ecology 82: 920-932. https://doi.org/10.1890/00129658(2001)082[092 0:TMAGIS] 2.0.CO;2.

Ewers RM, Didham RK, Fahrig L et al. 2011. A large scale forest fragmentation experiment: the stability of altered forest ecosystem project. Philosophical Transactions of the Royal Society B 366: 3292-3302. https:/ / doi.org/10.1098/rstb.2011.0049.

Ewers RM, Boyle MJW, Gleave RA et al. 2015. Logging cuts the functional importance of invertebrates in tropical rainforest. Nature Communications 6: 6836 . https://doi.org/10.1038/ncomms7836.

Fan ZX, Zhang SB, Hao GY, Ferry Slik JW \& Cao KF. 2012. Hydraulic conductivity traits predict growth rates and adult stature of 40 Asian tropical tree species better than wood density. Journal of Ecology 100: 732-741. https://doi.org/10.1111/j.1365-2745.2011.01939.x.

FichtLer E \& Worbes M. 2012. Wood anatomical variables in tropical trees and their relation to site conditions and individual tree morphology. Iawa Journal 33: 119 140. https://doi.org/10.1163/22941932-90000084.

Freund MB, Henley BJ, Karoly DJ, Mcgregor HV, Abram NJ, Dommenget D. 2019. Higher frequency of Central Pacific El Niño events in recent decades relative to past centuries. Nature Geoscience 12: 450-455. https:// doi.org/10.1038/s41561-019-0353-3.

Gaveau DLA, Sloan S, Molidena E et al. 2014. Four decades of forest persistence, clearance and logging on Borneo. PLoS ONE 9: e101654. doi:10.1371/journal. pone.0101654.g006.

Hacke UG, Sperry JS, Wheeler JK, Castro L. 2006. Scaling of angiosperm xylem structure with safety and efficiency. Tree Physiology 26:689-701. https://doi. org/10.1093/treephys/26.6.689.

Herbert JM \& Dixon RW. 2003. Is the ENSO phenomenon changing as a result of global warming? Physical Geography 23: 196-211. https://doi. org/10.2747/0272-3646.23.3.196.

IAWA CommitTeE. 1989. IAWA list of microscopic features for hardwood identification. International Association of Wood Anatomists Bulletin, New Series 10: 219-332.

ipCG (Intergovernmental Panel on Climate Change). 2013. Climate change 2013: The physical science basis. Intergovernmental Panel on Climate Change, Working Group I Contribution to the IPCCFifth Assessment Report (AR5). Cambridge University Press, Cambridge.

IsLAM M, RAHMAN M \& BRÄUNING A. 2018. Long-term hydraulic adjustment of three tropical moist forest tree species to changing climate. Frontiers in Plant Science. 9: 1761. doi: 10.3389/fpls.2018.01761. https://doi. org $/ 10.3389 /$ fpls.2018.01761.

Islam M, RAHMAN M \& BRÄUning A. 2019. Long-term wood anatomical time series of two ecologically contrasting tropical tree species reveal differential hydraulic adjustment to climatic stress. Agricultural and Forest Meteorology 265: 412-423. https://doi.org/10.1016/j. agrformet.2018.11.037.

Johansen DA. 1940. Plant Microtechnique. McGraw-Hill Book Company, New York.

Jucker T, Hardwick SR, Both S et al. 2018. Canopy structure and topography jointly constrain the microclimate of human-modified tropical landscapes. Global Change Biology 24: 5243-5258. https://doi.org/10.1111/ gcb.14415.

King DA, Davies SJ, Tan S \& Noor NSM. 2006. The role of wood density and stem support costs in the growth and mortality of tropical trees. Journal of Ecology 94: 670-680. https://doi.org/10.1111/j.13652745.2006.01112.x 
Lewis SL, Edwards DP, Galbratth D ET Al. 2015. Increasing human dominance of tropical forests. Science 349 827-832. doi: 10.1126/science.aaa9932.

Martínez-Cabrera Hi, Jones CS, Espino S \& Jochen Schenk H. 2009. Wood anatomy and wood density in shrubs: Responses to varying aridity along transcontinental transects. American Journal of Botany 96: 1388-1398. doi:10.3732/ajb.0800237.

Mayfield MM, Dwyer JM, Chalmandrier L et al. 2013. Differences in forest plant functional trait distributions across land-use and productivity gradient. American Journal of Botany 100: 1356-1368. doi:10.3732/ajb.1200461.

McAlpine CA, Johnson A, Salazar A et al. 2018. Forest loss and Borneo's climate. Environmental Research Letters. 13: 044009. https://doi.org/10.1088/1748-9326/ aaa4ff.

Meinzer FC, Clearwater MJ \& Goldstein G. 2001. Water transport in trees: current perspectives, new insights and some controversies. Environmental and Experimental Botany 45: 239-262. https://doi. org/10.1016/S0098-8472(01)00074-0.

Morris H, Gillingham MAF, Plavcová L et al. 2018. Vessel diameter is related to amount and spatial arrangement of axial parenchyma in woody angiosperms. Plant Cell and Environment 41: 245-260. https://doi.org/10.1111/pce.13091.

Mouillot D, Graham NAJ, Villéger S, Mason NWH \& BELlwoOd DR. 2013. A functional approach reveals community responses to disturbances. Trends in Ecology and Evolution 28: 167-177. https://doi. org $/ 10.1016 /$ j.tree.2012.10.004.

Olson ME, Anfodillo T, Rosell JA et al. 2014. Universal hydraulics of the flowering plants: vessel diameter scales with stem length across angiosperm lineages, habits and climates. Ecology Letters 17: 988-997. https://doi.org/10.1111/ele.12302.

Olson ME \& Rosell JA. 2013. Vessel diameter-stem diameter scaling across woody angiosperms and the ecological causes of xylem vessel diameter variation. New Phytologist 197: 1204-1213. doi: 10.1111/nph.12097.

Osazuna-Peters Ol, Jiménez I, Oberle B, Chapman CA \& Zanne AE. 2015. Selective logging: do rates of forest turnover in stems, species composition and functional traits decrease with time since disturbance? A 45 year perspective. Forest Ecology and Management 357: 10-21. https://doi.org/10.1016/j. foreco.2015.08.002

Pérez-Harguindeguy N, Díaz S, Garnier E et al. 2013. New handbook for standardised measurement of plant functional traits worldwide. Australian Journal of Botany 61: 167-234. http://dx.doi.org/10.1071/ BT12225.

Pfeifer M, Kor L, Nilus R eT aL. 2016. Mapping the structure of Borneo's tropical forests across a degradation gradient. Remote Sensing of Environment 176: 84-97. https://doi.org/10.1016/j.rse.2016.01.014.

Poorter L, Mcdonald I, Alarco A et al. 2010. The importance of wood traits and hydraulic conductance for the performance and life history strategies of 42 rainforest tree species. New Phytologist 185: 481-492. https://doi.org/10.1111/j.14698137.2009.03092.x.
Preston KA, Cornwell WK, Denoyer JL. 2006. Wood density and vessel traits as distinct correlates of ecological strategy in 51 California Coast Range angiosperms. New Phytologist 170: 807-818.

Qie L, Lewis SL, Sullivan MJP et al. 2017. Longterm carbon sink in Borneo's forests halted by drought and vulnerable to edge effects. Nature Communications 8: 1966. https://doi.org/10.1038/ s41467-017-01997-0.

R Core Team. 2017. R: A language and environment for statistical computing. R Foundation for Statistical Computing. http:/ /www.R-project.org/.

Robert EMR, Koedam N, Beeckman H \& Schmitz N. 2009. A safe hydraulic architecture as wood anatomical explanation for the difference in distribution of the mangroves Avicennia and Rhizophora. Functional Ecology 23: 649-657.

Schmitz N, Verheiden A, Beeckman H, Kairo JG \& Koedam N. 2006. Influence of a salinity gradient on the vessel characters of the mangrove species Rhizophora mucronata. Annals of Botany 98: 1321-1330.

Scholz A, Klepsch M, Karimi Z \& Jansen S. 2013. How to quantify conduits in wood? Frontiers in plant science 4: 1-11. https://doi.org/10.3389/fpls.2013.00056.

Schreiber SG, Hacke UG \& Hamann A. 2015. Variation of xylem vessel diameters across a climate gradient: Insight from a reciprocal transplant experiment with a widespread boreal tree. Functional Ecology 29: 1392-1401. doi: 10.1111/1365-2435.12455.

Scriven SA, Hodgson JA, Mcclean CJ \& Hill JK. 2015. Protected areas in Borneo may fail to conserve tropical forest biodiversity under climate change. Biological Conservation 184: 414-423. https://doi. org/10.1016/j.biocon.2015.02.018.

SLIK JWF. 2004. El Niño droughts and their effects on tree species composition and diversity in tropical rain forests. Oecologia 141: 114-120. doi: 10.1007/s00442004-1635-y.

Slik JWF, Kessler PJA \& VAn Welzen PC. 2003. Macaranga and Mallotus species (Euphorbiaceae) as indicators for disturbance in the mixed lowland dipterocarp forest of East Kalimantan (Indonesia). Ecological Indicators 2: 311-324. https://doi.org/10.1016/ S1470-160X(02)00057-2.

Soepadmo E, SAw LG \& Chung RCK. 2004. Tree Flora of Sabah and Sarawak. Volume 5. Forest Research Institute Malaysia, Kepong.

Sperry JS, Nichols KL, Sullivan JeM \& Eastlack SE. 1994. Xylem embolism in ring-porous, diffuseporous, and coniferous trees of Northern Utah and interior Alaska. Ecology 75: 1736-1752. https://doi. org $/ 10.2307 / 1939633$.

STILL MJ. 1993. Population dynamics and spatial patterns of dipterocarp seedlings in a tropical rain forest. $\mathrm{PhD}$ thesis, University of Stirling, Stirling.

Susanto D, Ruchiyat D, Sutisna M \& Amirta R. 2016. Flowering, fruiting, seed germination and seedling growth of Macaranga gigantea. Biodiversitas 17: 192199. https://doi.org/10.13057/biodiv/d170128.

TNG DYP, APGAUA DMG, IsHIDA YF ET AL. 2018. Rainforest trees respond to drought by modifying their hydraulic architecture. Ecology and Evolution 8: 12479-12491. https://doi.org/10.1002/ece3.4601. 
Tyree TM \& Zimmerman HM. 2002. Xylem Structure and the Ascent of Sap. Springer, Berlin.

Van Nieunstadt MGL \& Sheil D. 2005. Drought, fire and tree survival in a Borneo rain forest, East Kalimantan, Indonesia. Journal of Ecology 93: 191-201. https://doi.org/10.1111/j.13652745.2004.00954.x.

Verburg R \& Van Eijk-Bos C. 2003. Effects of selective logging on tree diversity, composition and plant functional type patterns in a Bornean rain forest. Journal of Vegetation Science 14: 99-110. https://doi. org/10.1111/j.1654-1103.2003.tb02132.x.

Walsh RPD \& Newbery DM. 1999. The ecoclimatology of Danum, Sabah, in the context of the world's rainforest regions, with particular reference to dry periods and their impact. Philosophical Transactions of the Royal Society B: Biological Sciences 354: 1869-1883. https://doi.org/10.1098/rstb.1999.0528.

Westoby M \& Wright IJ. 2006. Land-plant ecology on the basis of functional traits. Trends in Ecology and Evolution 21: 261-268. https://doi.org/10.1016/j. tree.2006.02.004.
Wilcove DS, Giam X, Edwards DP, Fisher B \& KoH LP. 2013. Navjot's nightmare revisited: logging, agriculture, and biodiversity in Southeast Asia. Trends in Ecology and Evolution 28: 531-540. https://doi. org/10.1016/j.tree.2013.04.005.

Zanne AE, Westoby M, Falster DS et al. 2010. Angiosperm wood structure: global patterns in vessel anatomy and their relation to wood density and potential conductivity. American Journal of Botany 97: 207-215. https://doi.org/10.3732/ajb.0900178.

Zhang K, De Asslmeida Castanho AD, Galbraith DR et al. 2015. The fate of Amazonian ecosystems over the coming century arising from changes in climate, atmospheric $\mathrm{CO}_{2}$, and land use. Global Change Biology 21: 2569-2587. https://doi.org/10.1111/gcb.12903

ZiemińsKa K, Butler DW, Gleason SM, Wright IJ \& WeSToby M. 2013. Fibre wall and lumen fractions drive wood density variation across 24 Australian angiosperms. AoB Plants 5: plt046. https://doi.org/10.1093/ aobpla/plt046. 